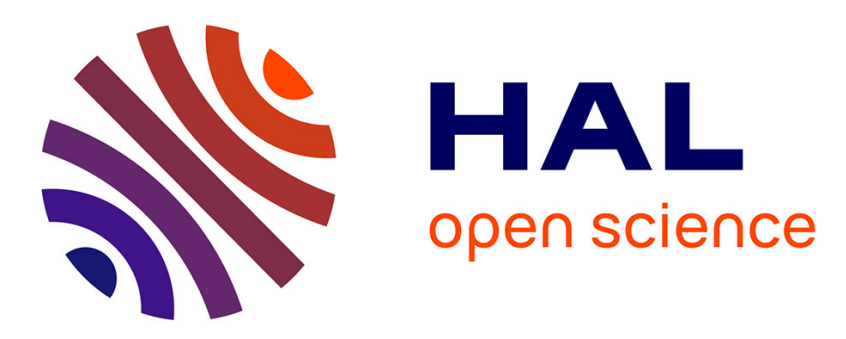

\title{
No significant transfer of the rare earth element samarium from spiked soil to alfalfa by Funneliformis mosseae
}

Ruoyu Hu, Thierry Beguiristain, Alexis de Junet, Corinne Leyval

\section{- To cite this version:}

Ruoyu Hu, Thierry Beguiristain, Alexis de Junet, Corinne Leyval. No significant transfer of the rare earth element samarium from spiked soil to alfalfa by Funneliformis mosseae. Mycorrhiza, 2020, 30 (6), pp.761-771. 10.1007/s00572-020-00991-7 . hal-03015379

\section{HAL Id: hal-03015379 \\ https://hal.univ-lorraine.fr/hal-03015379}

Submitted on 19 Nov 2020

HAL is a multi-disciplinary open access archive for the deposit and dissemination of scientific research documents, whether they are published or not. The documents may come from teaching and research institutions in France or abroad, or from public or private research centers.
L'archive ouverte pluridisciplinaire HAL, est destinée au dépôt et à la diffusion de documents scientifiques de niveau recherche, publiés ou non, émanant des établissements d'enseignement et de recherche français ou étrangers, des laboratoires publics ou privés. 


\title{
No significant transfer of the rare earth element samarium from spiked soil to alfalfa by Funneliformis mosseae
}

\author{
Ruoyu HU, Thierry BEGUIRISTAIN, Alexis DE JUNET, Corinne LEYVAL* \\ Université de Lorraine, CNRS, LIEC, F-54000 Nancy, France \\ * Corresponding author: corinne.leyval@univ-lorraine.fr, tel. 33(0)372745204
}

\begin{abstract}
Rare earth elements including samarium have been widely used in modern technologies in recent decades. Following over-exploitation and soil contamination, they can accumulate in plants and be toxic at high concentrations. Arbuscular mycorrhizae benefit plants in metal-contaminated soils by improving their survival and growth and alleviating metal toxicity, but little information is available about soil contaminated by rare earth elements. We performed two experiments using samarium to study the role of arbuscular mycorrhizal fungi on plant growth and samarium transfer to alfalfa in a samarium-spiked soil. A pot experiment was conducted in a soil spiked with two concentrations of samarium and a non-spiked control, inoculated or not with a metaltolerant Funneliformis mosseae. A compartmented pot experiment was then performed with a separated compartment containing samarium-spiked sand only accessible by F.mosseae fungal hyphae to further study the transport of samarium from the soil to alfalfa. The biomass of alfalfa grown on samarium-spiked soil was reduced, while it was significantly higher following arbuscular mycorrhiza inoculation in the pot experiment, both in the control and samarium-spiked soil. Although mycorrhizal plants had a higher phosphorus content than non-mycorrhizal ones, there was no significant difference in samarium concentrations between mycorrhizal and non-mycorrhizal plants. The compartment experiment confirmed that there was no significant samarium transfer to the plant by F.mosseae. Other fungi and plants should be tested, and field experiments performed, but our results suggest that arbuscular mycorrhizal plants might be considered in phytorestoration of rare-earthcontaminated soils.
\end{abstract}

\section{Keywords}

Rare earth element, Funneliformis mosseae, Compartment experiment, Metal tolerance

\section{Introduction}

Rare earth elements (REEs) are a group of elements that comprise 15 lanthanides and yttrium (Y). Despite their name, they are rather abundant in the earth crust, as abundant as some metallic trace elements (MTEs). Due to exceptional conductivity, magnetic and other properties, REEs have been increasingly used in advanced technologies and industries. The potential anthropogenic input of REEs to natural ecosystems and to the food chain will increase correspondingly in the near future (Jiang et al. 2012; Falandysz et al. 2017). In parallel, the over-exploitation of REE ores can cause a dramatic issue to local environment, with large amounts of REE deposits in soil (Li et al. 2010; Liang et al. 2014).

Samarium (Sm) is a lanthanide found half-way among the 15 lanthanides in the periodic table. It is the fifth most abundant REE with about 700 tons of Sm oxide production every year (Zhang et al. 2014). It has been used in lasers, magnets, screens, catalysts, and fertilizers (Zhang et al. 2014; Pagano 2016). This wide use has 
made it one of the REEs with the highest commercial interest (Massari and Ruberti 2013). REEs can accumulate in crops and wild plants and be toxic at high concentrations (Carpenter et al. 2015; Pagano 2016). Sm is not only phytotoxic at high concentrations, but has also been reported to be toxic to mammals (Zhang et al. 2014). The toxicity of REEs depends on their bioavailability, which can be affected by their sources and forms and also by soil parameters like the pH, particle size and organic matter (Babula et al. 2008; MacMillan et al. 2019). Other elements such as calcium can affect the bioavailability of light REEs because the uptake of light REEs by plant roots involves Ca channels (Lansman 1990; Yuan et al. 2017).

Arbuscular mycorrhizal (AM) symbiosis represents the most common symbiotic association between fungi and plants and can be found in the roots of $90 \%$ of plants on earth. AM fungi bring remarkable benefits to plant growth, especially in stressful conditions like polluted soils. Many studies have been carried out on the effects of AM fungi on plants growing in MTE-polluted soils: AM fungi decrease MTE concentrations in plants and increase plant biomass (Haselwandter et al. 1994; Leyval et al. 1997; Hildebrandt et al. 2007). This beneficial effect of AM fungi on plant growth and a lower metal concentration in AM plants have been found for cadmium (Cd) in maize (Chen et al. 2004; Chang et al. 2018), alfalfa (Redon et al. 2008), and tobacco (Janoušková et al. 2005). They have also been shown for copper $(\mathrm{Cu})$ in both $\mathrm{Cu}$-mine-tailing soil (Da Silva et al. 2005; Chen et al. 2007) and spiked soil (Merlos et al. 2016); for zinc (Zn) in maize grown in Zn-spiked soil (Zhang et al. 2010), and in plants growing in Zn waste soil (Turnau et al. 2001); and finally for lead (Pb) (Hovsepyan and Greipsson, 2004). AM hyphae transported Cd from the soil to the roots in a compartmented pot and radioactive $\mathrm{Cd}$ experiment (Joner and Leyval 1997; Chen et al. 2018). However, no AM transport of caesium (Cs) or europium (Eu) to Medicago truncatula occurred using the same experimental approach (Joner et al., 2004). Despite the large number of studies carried out on the effects of AM fungi on plants in MTEpolluted soils, few data are available on the effects of AM fungi on plant growth and REE transfer to plants in REE-contaminated soils, and such studies concern only Eu and lanthanum (La) (Joner et al. 2004; Chang et al. 2018).

Many studies have compared different AM fungi for their tolerance to MTE and showed that AM fungi isolated from MTE-contaminated soils were more tolerant to $\mathrm{Cd}$ and $\mathrm{Zn}$ than isolates from non-contaminated soils (Weissenhorn et al. 1993; Joner et al. 2000; Joner and Leyval 2001; Rivera-Becerril 2002; Rivera-Becerril et al. 2005). Metal-tolerant AM fungi are more efficient to improve plant growth and reduce metal uptake by plants than less tolerant ones (Redon et al. 2009). To date, information on whether AM fungi can also be tolerant to other trace elements such as REEs is lacking.

The objective of our study was to investigate the effect of an AM fungus on plant growth and on REE transfer to plants in an REE-contaminated soil, using Sm as a model REE. We performed two experiments using the model legume alfalfa, inoculated or not with a metal-tolerant Funneliformis mosseae. Mycorrhizal and nonmycorrhizal alfalfa plants were first grown in pots with Sm-spiked soil. Then a compartment experiment was performed to determine whether hyphae could transfer Sm to plants. Alfalfa was grown in a top compartment without added Sm, separated from a bottom compartment spiked with Sm by two kinds of mesh to allow hyphal crossing and limit diffusion.

\section{Materials and methods}

Soil, plant and arbuscular mycorrhizal fungus 
The soil used in both experiments was a Luvisol collected $(5-25 \mathrm{~cm}$ deep) in north-eastern France (Bouzule, 48 $44^{\prime} 7.95^{\prime \prime} \mathrm{N}, 6^{\circ} 19^{\prime} 9.64^{\prime \prime} \mathrm{E}$ ). The sampled soil was air-dried, ground, sieved to $2 \mathrm{~mm}$ and then homogenised and stored in a cool, dry and dark room prior to the experiments. Its physico-chemical characteristics are presented in Table 1. The soil was amended and homogenized with 2-mm, pre-sieved and washed sand (30\% sand $/ 70 \%$ soil) to prevent compaction. Both experiments were carried out using the model legume alfalfa (Medicago sativa L. var. Europe), which grows rapidly. The AM fungus used in the experiments was metal-tolerant F. mosseae strain BEG 69. It was isolated from a soil with a 60 -year history of industrial metal pollution (Weissenhorn et al. 1993; Tonin et al. 2001), and is kept as a permanent culture on the contaminated soil using leek as host plant in our laboratory.

\section{Experimental design}

\section{Pot experiment}

Alfalfa was grown in $1 \mathrm{~kg}$ pots, with (M) or without (NM) AM inoculation, filled with soil spiked with 2 concentrations of $\mathrm{Sm}\left(100\right.$ and $200 \mathrm{mg} \cdot \mathrm{kg}^{-1}$, using $\mathrm{SmCl}_{3} \cdot 6 \mathrm{H}_{2} \mathrm{O}$ solution) and a control without Sm addition. Four replicates were prepared for each treatment. The spiking concentrations were chosen according to the results of preliminary experiments ( $\mathrm{Hu}$ et al. 2020). After spiking, the soil was dried at $60{ }^{\circ} \mathrm{C}$ and thoroughly homogenized. Spiked or non-spiked soil was used to fill the pots evenly, and deionized water was added to reach $70 \%$ of water holding capacity (WHC). The pots were stored at $4^{\circ} \mathrm{C}$ in a dark room (T0) for 21 days of ageing. Soil samples were collected at T0, dried at $80{ }^{\circ} \mathrm{C}$ and ground for $\mathrm{Sm}$ analysis. After the ageing period, 15 pregerminated alfalfa (3-4-day-old) seedlings were transplanted into each pot. Prior to transplantation, mycorrhizal pots were inoculated with approximately 200 spores of $F$. mosseae BEG 69 extracted from a pot culture on leek and added to the soil at $3 \mathrm{~cm}$ depth. The non-inoculated pots received an equal amount of deionized water at the same depth. The planted pots were transferred to a growth chamber with a $16 \mathrm{~h}$ photoperiod, $22^{\circ} \mathrm{C} / 18^{\circ} \mathrm{C}$ day/night, $250 \mu \mathrm{mol}$ photons $\mathrm{m}^{-2} \cdot \mathrm{s}^{-1}$, and $80 \%$ relative humidity. Plants were watered twice a week to maintain $70 \%$ WHC.

Alfalfa shoots and roots were harvested 49 days after transplantation. The shoot samples were rinsed carefully 4 times with deionized water, then dried, weighed and finely ground for Sm, P, calcium (Ca), magnesium $(\mathrm{Mg})$, potassium $(\mathrm{K})$ and sodium $(\mathrm{Na})$ analysis. The root samples were cleaned in the same way and were stained with the trypan blue method to determine mycorrhizal colonization (Koske and Gemma 1989). Thirty 1-cm pieces of stained root segments were sealed on slides, and arbuscular mycorrhizal colonization was observed and determined according to the protocol of Trouvelot et al. (1986).

\section{Compartment experiment}

Alfalfa plants inoculated or not with F. mosseae were grown in compartmented pots where only AM hyphae could access the bottom compartment containing $100 \mathrm{mg} \mathrm{kg}^{-1}$ spiked Sm. The compartmented pots consisted of a plant compartment made of a 150-mm tall polyvinyl chloride (PVC) tube (50 mm outer diameter, $45 \mathrm{~mm}$ inner diameter), and a Sm-spiking bottom compartment made of a 30-mm tall PVC tube with the same diameter separated by a nylon mesh (Supplementary Fig. 1). Two kinds of nylon mesh were used: a one-layer 37 $\mu \mathrm{m}$ mesh and a 3-layer $(37 \mu \mathrm{m}, 1000 \mu \mathrm{m}$ and $37 \mu \mathrm{m})$ mesh, called air-mesh below, forming a $0.5 \mathrm{~mm}$ air gap between the two compartments (Joner et al. 2004). 
The bottom compartment was filled with $65 \mathrm{~g}$ of Fontainebleau sand (EINECS: 238-878-4) spiked with $100 \mathrm{mg} \cdot \mathrm{kg}^{-1} \mathrm{Sm}\left(365 \mathrm{mg} \cdot \mathrm{kg}^{-1} \mathrm{SmCl}_{3} \cdot 6 \mathrm{H}_{2} \mathrm{O}\right)$ and deionized water to reach $70 \% \mathrm{WHC}$. The main compartment contained $250 \mathrm{~g}$ of soil watered with deionized water to reach $70 \% \mathrm{WHC}$. Half of the pots were inoculated with approximately 200 spores of $F$. mosseae BEG 69 in the main compartment. Five pre-germinated alfalfa (3-4day-old) seedlings were transplanted into each pot in the main compartment. Each of the four treatments was carried out in three replicates. All the pots were transferred to the growth chamber with the same conditions as the pot experiment. Plants were watered twice a week to maintain $70 \%$ WHC.

Alfalfa shoots and roots were sampled separately 42 days after transplantation. The shoot samples were rinsed 3 times with deionized water. The root samples were rinsed 3 times with deionized water, then transferred to $5-\mathrm{mM}$ ice-cold $\mathrm{CaCl}_{2}$ solution for $15 \mathrm{~min}$ to remove the soil particles and adsorbed mineral elements from the root surface, and washed with running deionized water (Han et al. 2004). The samples were dried at $60{ }^{\circ} \mathrm{C}$ and weighed before being ground for Sm, P and Ca analysis. Root samples were blotted dry with paper towels and weighed. One root sub-sample was preserved in $70 \%$ ethanol solution to measure arbuscular mycorrhizal colonization as described above. Another root sub-sample was weighed before drying at $60{ }^{\circ} \mathrm{C}$, weighed and ground for Sm, P and Ca analysis. Total dry weight was calculated using the total fresh weight along with the fresh and dry weights of the sub-samples.

\section{Sm and nutrient element analysis}

The total Sm concentration in the soil samples from both experiments was assessed by Aqua Regia digestion. Two hundred mg of ground soil were digested with $10 \mathrm{~mL}$ of Aqua Regia (nitric acid: hydrochloric acid 1:3 v/v) in an acid-cleaned Teflon tube of the CEM Mars 5 Digestion Microwave System ${ }^{\circledR}$, and then processed with the digestion program: $15 \mathrm{~min}$ digestion at $25^{\circ} \mathrm{C}$ and $10 \mathrm{~min}$ digestion at $170^{\circ} \mathrm{C}$. Samples were then filtered (DigiFILTER, SCP Science ${ }^{\circledR}$ 010-500-070), and the volume was calibrated to $10 \mathrm{~mL}$ with ultrapure deionized water $18 \mathrm{M} \Omega$ and preserved at $4{ }^{\circ} \mathrm{C}$ until analysis.

The soil available Sm concentration was determined using the DTPA extraction method (Carter and Gregorich 2007; Kim et al. 2015) based on preliminary experiments (Hu et al. 2020). One g of ground soil sample was added to $10 \mathrm{~mL}$ of DTPA reagent consisting of diethylenetriaminepentaacetic acid (DTPA) $(0.005 \mathrm{M}), \mathrm{CaCl}_{2}(0.01 \mathrm{M})$ and triethanolamine $(0.1 \mathrm{M})$. Samples were homogenized and centrifuged. The supernatants were filtered and calibrated to $10 \mathrm{~mL}$ with ultra-pure deionized water $18 \mathrm{M} \Omega$ and preserved at $4{ }^{\circ} \mathrm{C}$ until analysis.

The ground shoot and root samples $(200 \mathrm{mg})$ were transferred into DigiTUBEs with $6 \mathrm{~mL}$ of $69 \%$ $\mathrm{HNO}_{3}\left(\mathrm{CAS}\right.$ : 7697-37-2) and $3 \mathrm{~mL}$ of $30 \% \mathrm{H}_{2} \mathrm{O}_{2}\left(\mathrm{w} / \mathrm{w} \mathrm{H} \mathrm{H}_{2} \mathrm{O}\right)(\mathrm{CAS}: 7722-84-1)$ at room temperature overnight. Then, the samples were processed in a DigiPREP MS 48 \& TS (SCP Science ${ }^{\circledR}$ 010-500-205 \& 010-500-275) hot plate system with a digestion program adapted to plant tissues with 5 min solubilization at $45^{\circ} \mathrm{C}, 10 \mathrm{~min}$ predigestion at $65{ }^{\circ} \mathrm{C}$ and $60 \mathrm{~min}$ digestion at $95{ }^{\circ} \mathrm{C}$. Then, the solutions were filtered and preserved at $4{ }^{\circ} \mathrm{C}$ until analysis.

For the pot experiment, shoot $\mathrm{Sm}, \mathrm{P}, \mathrm{Na}, \mathrm{Mg}, \mathrm{K}$ and $\mathrm{Ca}$ concentrations were analyzed by inductively coupled plasma-optical emission spectroscopy (ICP-OES), using certified soil NCS® Reference Material DDC 73030 Soil as a reference. The detection limits for Sm concentrations in the plant and soil samples by ICP-OES were 0.02 and $0.05 \mathrm{mg} \cdot \mathrm{kg}^{-1}$, respectively. For the compartment experiment, $\mathrm{Sm}, \mathrm{P}$ and $\mathrm{Ca}$ were analysed in the root and shoot samples using inductively coupled plasma mass spectrometry (ICP-MS), using the certified 
reference material BCR ${ }^{\circledR}-667$ estuarine sediment (rare elements, Th, $U$ ) as a reference. The detection limit for Sm concentration in the plant samples analyzed by ICP-MS was $0.0001 \mathrm{mg} \cdot \mathrm{kg}^{-1}$.

\section{Data analysis}

The data obtained in both experiments were analyzed using XLSTAT version 2020.3. Statistical analyses were performed using two-way analysis of variance (ANOVA) and Tukey's honestly-significantdifference (HSD) post-hoc test. For the non-normally distributed data parameters, we used rank-transformed data. Mycorrhizal colonization data were arcsine transformed before statistical analyses. The data presented in the figures are the means \pm standard deviations (SDs). $P$-values are given in the figure legends.

\section{Results}

\section{Pot experiment}

The Sm concentration was analyzed in the soil just after spiking (T0). It was $83.07 \pm 14.88 \mathrm{mg} \cdot \mathrm{kg}^{-1}$ and $158.48 \pm 24.65 \mathrm{mg} \cdot \mathrm{kg}^{-1}$ in the 100 and $200 \mathrm{mg} \cdot \mathrm{kg}^{-1} \mathrm{Sm}$ spiked treatments, respectively. In the non-spiked soil, it was $4.47 \pm 0.49 \mathrm{mg} \cdot \mathrm{kg}^{-1}$. DTPA-extractable $\mathrm{Sm}$ in the spiked soil was $27.31 \pm 0.83 \mathrm{mg} \cdot \mathrm{kg}^{-1}$ and $66.12 \pm 5.61$ $\mathrm{mg} \cdot \mathrm{kg}^{-1}$ in the 100 and $200 \mathrm{mg} \cdot \mathrm{kg}^{-1}$ spiked soils, respectively. In the non-spiked soil, it was $0.53 \pm 0.29 \mathrm{mg} \cdot \mathrm{kg}^{-1}$.

Alfalfa shoot biomass was significantly higher $(\sim 80 \%)$ for the mycorrhizal plants grown on the nonspiked and $100 \mathrm{mg} \cdot \mathrm{kg}^{-1}$ spiked soils than for the non-mycorrhizal ones $(P<0.0001)$ (Fig. 1a). However, it was

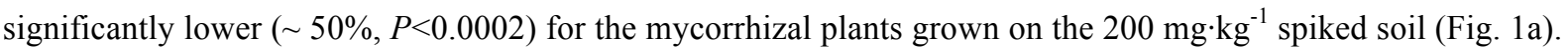
No mycorrhizal colonization was observed in the non-inoculated plants. Nodules were observed on alfalfa roots in most of the pots, without any clear differences among treatments.

There was a high frequency of mycorrhiza-colonized roots and arbuscules in the inoculated plants, indicating that F.mosseae colonized the roots of alfalfa and was active, despite variations among replicates (Table 2). Significantly higher arbuscular frequency and intensity were found in the plants grown on $100 \mathrm{mg} \cdot \mathrm{kg}^{-1}$ Sm spiked soil than in those grown on non-spiked soil. Mycorrhizal intensity, arbuscule frequency and intensity in roots were significantly lower in the $200 \mathrm{mg} \cdot \mathrm{kg}^{-1}$ than in the $100 \mathrm{mg} \cdot \mathrm{kg}^{-1} \mathrm{Sm}$ spiked soil, but not significantly different from the non-spiked treatment.

The shoot Sm concentration increased with $\mathrm{Sm}$ addition and with the spiking concentration. Sm was detected in alfalfa shoots $\left(0.16 \pm 0.02 \mathrm{mg} \cdot \mathrm{kg}^{-1}\right)$ in the non-spiked soil, but it increased to $1.08 \pm 0.38 \mathrm{mg} \cdot \mathrm{kg}^{-1}$ in the $100 \mathrm{mg} \cdot \mathrm{kg}^{-1}$ spiked soil and up to $2.70 \pm 0.51 \mathrm{mg} \cdot \mathrm{kg}^{-1}$ in the $200 \mathrm{mg} \cdot \mathrm{kg}^{-1}$ spiked soil. There was no significant difference between mycorrhizal and non-mycorrhizal plants (Fig. 2a and b).

The alfalfa shoot $\mathrm{P}$ concentration was not significantly affected by Sm spiking or AMF inoculation, and no significant difference was found among the treatments (Supplementary fig. 2). However, the P content was significantly affected by both Sm spiking and AMF inoculation (Fig. 1b, $P<0.001$ ). The shoot P content was significantly higher in mycorrhizal than in non-mycorrhizal plants in the non-spiked and $100 \mathrm{mg} \cdot \mathrm{kg}^{-1} \mathrm{spiked} \mathrm{soil}$ and not significantly higher in the $200 \mathrm{mg} \cdot \mathrm{kg}^{-1}$ spiked soil. The shoot $\mathrm{P}$ content was significantly lower in the plants grown on $200 \mathrm{mg} \cdot \mathrm{kg}^{-1}$ spiked soil than in those grown on non-spiked soil.

Shoot $\mathrm{Na}, \mathrm{Mg}, \mathrm{K}$ and $\mathrm{Ca}$ concentrations were not affected by Sm spiking, while AMF inoculation significantly decreased shoot Ca concentrations in all Sm treatments, shoot Na concentration in the $100 \mathrm{mg} \cdot \mathrm{kg}^{-1}$ spiked soil, and $\mathrm{K}$ and $\mathrm{Mg}$ concentrations in the non-spiked soil (Supplementary fig. 2). The shoot contents in these elements decreased with increased Sm spiking. However, significant differences in $\mathrm{Mg}$ and $\mathrm{Na}$ contents 
were only observed between mycorrhizal plants grown on non-spiked soil and non-mycorrhizal plants grown on $200 \mathrm{mg} \cdot \mathrm{kg}^{-1} \mathrm{Sm}$ spiked soil. Shoot K and Ca contents were significantly lower in the plants grown on $200 \mathrm{mg} \cdot \mathrm{kg}^{-}$ ${ }^{1}$ spiked soil than in those grown on non-spiked soil. The shoot contents of these elements tended to increase with AMF inoculation, but differences among treatments were not significant.

\section{Compartment experiment}

Shoot biomass did not significantly differ among the four treatments in the compartment experiment (Fig. 3a). Root biomass was significantly affected by mesh size $(P<0.05)$, but it was only significantly different between mycorrhizal plants grown in 37- $\mu \mathrm{m}$ mesh pots and non-mycorrhizal ones grown in air-mesh pots $(P<0.05$, Fig. 3a). As in the first experiment, a good level of mycorrhizal root colonization by F.mosseae BEG 69 was observed, with the presence of arbuscules in pots with the two kinds of mesh (both above $25 \%$ mycorrhizal frequency) (Table 2).

The alfalfa root $\mathrm{Sm}$ concentrations and the Sm contents in both alfalfa shoots and roots were not significantly different among the treatments (Fig. 4), although higher values were observed in the plants grown in the $37-\mu \mathrm{m}$ mesh pots than in those grown in the air-mesh pots. However, the Sm concentration in alfalfa shoots was significantly higher in the plants grown in the $37-\mu \mathrm{m}$ mesh pots than in those grown in the air-mesh pots ( $\mathrm{F}=28.174, P=0.001)$, especially for non-mycorrhizal plants. But no significant difference in Sm shoot and root concentration or content was observed between mycorrhizal and non-mycorrhizal plants.

The $\mathrm{P}$ concentration and content in alfalfa shoots and roots were both affected by mycorrhizal inoculation (two-way ANOVA, $P<0.05$ for shoot concentration and $P \leq 0.006$ for shoot content). However, significant differences were observed only for the shoot content with both kinds of mesh and for the root content in air-mesh pots, with higher values in mycorrhizal plants (Fig. 3b). The shoot and root P contents were also significantly affected by the mesh type, and significantly higher with the 37- $\mu \mathrm{m}$ mesh than the air mesh for nonmycorrhizal plants (Fig. 3b). When it comes to the root $\mathrm{Ca}$ concentration and content, no significant difference was observed among treatments because of high variance among replicates (Supplementary Fig. 3). However, the shoot $\mathrm{Ca}$ concentration was significantly lower in mycorrhizal than non-mycorrhizal plants in air-mesh pots (Supplementary Fig. 3).

\section{Discussion}

In the pot experiment, the alfalfa shoot dry weight was significantly higher due to AM inoculation, indicating a beneficial effect of F.mosseae on alfalfa growth with or without Sm contamination. When the plants were grown on the Sm-spiked soil, although their biomass was reduced at the highest Sm concentration, there was an $80-100 \%$ increase of the shoot biomass of $F$. mosseae-inoculated plants as compared to the noninoculated ones. There was no significant effect of F.mosseae on alfalfa biomass in the compartment experiment, but the rootable soil volume was more limited than in the pot experiment and the plants did not grow on a Smcontaminated soil (only a limited amount of Sm may have been transferred to the main compartments by diffusion). AM fungi had a beneficial effect on plant growth in REE-contaminated soil in a pot experiment with maize and sorghum grown on mine tailing soil with multiple metal contamination including REEs (Guo et al. 2013), where Glomus versiforme substantially promoted plant biomass (over 200\%). To our knowledge, no other publication has reported such an effect of AM fungi on plant growth in REE-contaminated soils. Large numbers 
of studies have reported this beneficial effect on plants grown on soils historically polluted by metals. However, results differed depending on plants and AM fungi. Redon et al. (2009) tested the effect of AM fungi on barrel medics (Medicago trunculata) grown on heavy metal $(\mathrm{Pb}, \mathrm{Zn}, \mathrm{Cd}$ ) polluted agricultural soil; 4 out of the 5 fungi used in the experiment significantly increased shoot weight. Janoušková et al. (2005) studied the effects of two isolates of G.intraradices on a variety of tobacco in Cd-spiked soils and found a beneficial effect of AM fungi on tobacco plant growth, with differences among isolates. Rhizophagus irregularis helped maize to survive in soil spiked with a high concentration of $\mathrm{Cu}\left(500 \mathrm{mg} \cdot \mathrm{kg}^{-1}\right)$ by increasing shoot and root fresh weight by $15-90 \%$ (Merlos et al., 2016), but results differed depending on the $\mathrm{Cu}$ concentration and maize cultivar. For REEcontaminated soils, this beneficial effect of AM fungi on plant growth also may be fungus and host-plant dependent, because another AM fungus - G.mosseae - did not increase maize and sorghum growth (Guo et al. 2013).

The improved growth of AM plants is often attributed to nutritional effects, especially P nutrition. Together with the promotion of plant growth, F.mosseae increased the $\mathrm{P}$ content of alfalfa shoots in our pot experiment. The shoot $\mathrm{P}$ content almost doubled in AM-inoculated plants compared to the non-inoculated ones. This increased P content was found even in the highly Sm-contaminated mycorrhizal pots. The same increase in $\mathrm{P}$ content was also found in the compartment experiment with the two kinds of mesh, and in alfalfa roots in the air-mesh pots, although plant growth was not increased. In an experiment with REE mine tailings (Guo et al. 2013), G. versiforme increased P content by more than 2 fold in maize and 6 fold in sorghum shoots and roots, whereas the other AM species investigated, G.mosseae, had no effect.

The beneficial effect of AM fungi on plant nutrition is mainly documented for $\mathrm{P}$, which is a diffusionlimited element in the soil, while the effect on other nutrients is not usually as great. The promotion of nutrient uptake due to $\mathrm{AM}$ fungal colonization has been found in mining soil contaminated by $\mathrm{Zn}, \mathrm{Cd}$ and $\mathrm{Pb}$ (VogelMikuš et al. 2005): shoot and root $\mathrm{P}$ and $\mathrm{S}$ concentrations almost doubled, and the concentrations of mineral nutrients such as $\mathrm{K}, \mathrm{Ca}, \mathrm{Ni}$ and $\mathrm{Cu}$ also were significantly higher in $\mathrm{AM}$-inoculated plants. The $\mathrm{Ca}$ concentration was analyzed in our experiments because it may interact with REEs. It was not significantly affected in AMinoculated alfalfa in either experiment. However, the same results were obtained for the concentrations of other mineral nutrients such as $\mathrm{K}, \mathrm{Mg}$ and $\mathrm{Na}$, suggesting that there was no specific interaction between $\mathrm{Ca}$ and $\mathrm{Sm}$ uptake. The contents of these elements decreased with increased Sm concentration, probably due to the decreased biomass. In the study of Vogel-Mikuš et al. (2005), the soil was contaminated by several metals, while in our experiment only Sm was present. Chang et al. (2018) showed that maize plants grown in pots in La- and Cd-spiked soil had higher N, P and K concentrations than when grown on single metal-spiked soil and than the controls grown on non-spiked soil. However, there were no increased N, P, K concentrations in plants due to AM symbiosis and even a decrease in some of the treatments. Therefore, further experiments on multi-REE contamination could be considered to clarify the effect of AM fungi on plant nutrient uptake in REEcontaminated soils.

The influence of REE contamination on nutrient element uptake from the soil rarely has been studied, but a few reports indicate that application of REEs decreases nutrient concentrations in plants. La application to maize seedlings decreased root $\mathrm{K}$ concentration (Chang et al. 2018), while at a high concentration ( $>1 \mathrm{~g}$ REEs/plant, including La, Ce, Pr and Nd) P and Zn uptake by coconut palm was significantly reduced (Wahid et al. 2000). The concentrations of a few plant nutrients (K, Ca, Mg, $\mathrm{Zn}, \mathrm{Cu}, \mathrm{Mn})$ decreased in wheat seedlings 
grown on liquid media following exposure to $\mathrm{La}$ and $\mathrm{Ce}$ (Hu et al. 2002). In our study, Sm addition had no significant effect on the $\mathrm{P}$ concentration in alfalfa shoots, or on the shoot $\mathrm{K}, \mathrm{Ca}, \mathrm{Na}$, and $\mathrm{Mg}$ concentrations. However, compared to experiments with plants grown on nutrient solution ( $\mathrm{Hu}$ et al. 2002), our study was performed with Sm-spiked soil without any nutrient added. The shoot P, K and Ca contents were significantly lower in the alfalfa plants grown on Sm-spiked soil at the highest Sm concentration, but this could be due to the lower shoot biomass. Wang and Liang (2014) studied the effect of a REE mixture on P adsorption and desorption in 5 different soils and showed that it depended on their respective concentrations and on competitive adsorption between REE and phosphate ions on soil colloids. Grosjean et al. (2019) studied the effects of REEs on the growth and micro- and macro-nutrients of 5 hyperaccumulator Phytolacca species; they showed that the leaf $\mathrm{P}$ concentration was positively correlated with Sm concentrations, although it was more strongly correlated with heavy REEs. There was no evidence of interactions between Sm and nutrient uptake in plants in our study, but other REEs and soil types should be considered.

Besides promoting plant survival and growth in contaminated soils, AM fungi alleviate metal toxicity by decreasing plant uptake, although conclusions may differ (Pagano 2016). As far as REEs are concerned, no contribution of $G$. intraradices hyphae to $\mathrm{Eu}$ uptake by plants has been found (Joner et al., 2004). Claroideoglomus etunicatum had no significant effect on root and shoot La concentrations in a pot experiment with spiked soil (Chang et al., 2018). Results differed in a pot experiment with mine tailing soil contaminated with a mixture of REEs and heavy metals, depending on the plant and the fungal species (Guo et al. 2013). G. versiforme decreased La, cerium, praseodymium and neodymium in maize roots and shoots, but increased them in the roots of sorghum. However, no data were available for Sm. We observed no significant effect of $F$. mosseae on Sm uptake in either alfalfa shoots from the pot experiment or alfalfa shoots and roots from the compartment experiment. A higher Sm concentration was observed in the plants grown in the 37- $\mu \mathrm{m}$ mesh pots than in those grown in the air-mesh pots, regardless of the presence of AM fungi. However, this higher concentration was likely induced by Sm diffusion through the single-layer mesh, which was prevented in the air mesh pots by a $0.5-\mathrm{mm}$ air gap. A lot of studies have been carried out on the effect of metal contaminant uptake by AM fungi, but produced different results. Vogel-Mikuš et al. (2006) studied AM fungal colonization of the metal hyperaccumulator Thlaspi praecox grown on soil long contaminated by $\mathrm{Cd}, \mathrm{Zn}$ and $\mathrm{Pb}$. They compared AM-inoculated and non-inoculated plants in a pot experiment: AM colonization significantly decreased Cd, $\mathrm{Zn}$ and $\mathrm{Pb}$ shoot and root concentrations. The question of the direct uptake of metal pollutants by AM fungi has been a challenging issue because these fungi cannot to be cultured in the absence of host plants and it is difficult to distinguish fungal uptake from root uptake (Leyval et al. 1997). Therefore, some researchers used compartmented pots to only allow fungal hyphae access to the contaminant, and radiolabeled elements to have a strong signal and a low detection limit. A radioelement labeling experiment was carried out with a lateral compartment using ${ }^{109} \mathrm{Cd}$ to study Cd transfer through AM hyphae to plants (Joner and Leyval 1997). The shoot $\mathrm{Cd}$ concentration was not significantly influenced by ${ }^{109} \mathrm{Cd}$ spiking, but the root $\mathrm{Cd}$ concentration was significantly higher in AM-inoculated roots than in non-inoculated ones. This experiment showed that AM hyphae can transport $\mathrm{Cd}$ from the soil to the roots, but $\mathrm{Cd}$ translocation from the roots to the shoots was not increased by AM colonization. The hypothesis was that AM fungi can decrease MTE uptake by plants by immobilizing metals in the soil through sorption and by binding metals to intraradical fungal structures (Joner and Leyval 1997; Joner et al. 2000; Chen et al. 2018) or to extracellular polymeric substances possibly including 
glomalin-like proteins (Wu et al. 2016) reducing their root-to-shoot translocation. Joner et al. (2004) used radiocesium and bottom compartmented pots to study cesium (Cs) transfer by AM fungi to plants. They found no significant difference in Cs radioactivity between mycorrhizal and non-mycorrhizal roots and concluded that there was no significant transfer of Cs from fungal hyphae to plants. On the contrary, radiocesium was present in the roots and shoots of mycorrhizal Medicago truncatula plants in in vitro culture pots with mycorrhizal plants (Dupré De Boulois et al., 2006). The results of these in vitro and in vivo studies imply that the sorption capacity of soil clay, $\mathrm{K}$ bioavailability in the soil solution and the plant $\mathrm{K}$ nutritional status could explain the different results (Dupré de Boulois et al. 2008). We did not find evidence of any Sm transfer via AM hyphae to alfalfa, and the mechanisms involved are to be further investigated, but interactions with soil characteristics may have to be considered.

Among the studies on AM fungi in metal-polluted soils, Leyval et al. (1997) and Hildebrandt et al. (2007) reviewed the tolerance of AM fungi to metals and illustrated that certain AM fungi can adapt to high metal concentrations. F. mosseae BEG 69 was isolated from a site polluted with MTEs, and has been cultured since then on that metal-contaminated soil. This F.mosseae isolate has been found tolerant to $\mathrm{Cu}$ (Weissenhorn et al. 1995), Cd (Weissenhorn and Leyval 1995; Joner and Leyval 1997), and multiple heavy metals (Cd, Zn, Pb) (Redon et al. 2009). The metal-binding capacity of AM hyphae has been shown, especially for metal-tolerant isolates (Joner et al. 2000). This could contribute to explain the beneficial effect of these fungi on plant growth in metal-contaminated soils, as they retain toxic metals in mycorrhizal root structures and reduce metal uptake by the plants. However, the beneficial effect of G. intraradices on plant growth in a metal-contaminated soil was instead due to the elevated frequency of $\mathrm{N}$-fixing nodules (Redon et al., 2009). In the work of Janoušková et al. (2005), one isolate was more efficient to promote plant growth in the absence of $\mathrm{Cd}$, while another decreased the negative effect of $\mathrm{Cd}$ on plant growth. Therefore, different mechanisms may explain the improved growth of mycorrhizal plants in metal-contaminated soils. In our study, F. mosseae BEG 69 was tolerant to elevated soil Sm concentrations. The high colonization rate did not significantly decrease at $200 \mathrm{mg} . \mathrm{kg}^{-1}$. F. mosseae BEG 69 even showed higher arbuscule frequency and intensity in $100 \mathrm{mg} \cdot \mathrm{kg}^{-1} \mathrm{Sm}$ spiked soil than in the control without Sm added. No information is available on the ability of AM fungal structures to bind REEs, but the compartment experiment showed that there was no significant transfer of Sm through F. mosseae BEG69 hyphae.

\section{Conclusion}

The AM fungus F. mosseae BEG 69 colonized alfalfa roots even at the highest spiked concentration of $\mathrm{Sm}$. and significantly promoted alfalfa growth in Sm-spiked and non-spiked soil. This fungus, formerly isolated from MTE-contaminated soil, can tolerate high concentrations of Sm. Other AM fungi from different soils could be tested for their tolerance to REEs, including light and heavy REEs, and their ability to promote plant growth in REE-contaminated soils. This AM fungus increased the $\mathrm{P}$ content in both our pot and compartment experiments. The compartment experiment showed that $\mathrm{Sm}$ was not transferred from the soil to alfalfa roots by F. mosseae extraradical hyphae, in accordance with results previously reported on Eu. In order to have a better understanding of REE transfer in soil-AM fungi-plant systems, further studies should consider a combination of REEs and the interactions between REEs and soil constituents. Other fungi and plants should be tested, and field experiments performed, but our results suggest that the beneficial effect of AM fungi on plants in REEcontaminated soils could be considered for applications in phytoremediation or restoration strategies. 


\section{Acknowledgments}

This work was supported by the French National Research Agency through the national program "Investissements d'avenir" with the reference ANR-10-LABX-21- RESSOURCES21. The authors would like to thank the technical staff of LIEC, especially David BILLET, Christine FRIRY, Maximilien BEURET and Hervé MARMIER, and the Experimental phytotronic platform of Lorraine (PEPLor, Université de Lorraine).

\section{References}

Babula P, Adam V, Opatrilova R, Zehnalek J, Havel L, Kizek R (2008) Uncommon heavy metals, metalloids and their plant toxicity: A review. Environ Chem Lett 6:189-213. https://doi.org/10.1007/s10311-0080159-9

Carpenter D, Boutin C, Allison JE, Parsons JL, Ellis DM (2015) Uptake and Effects of Six Rare Earth Elements (REEs) on Selected Native and Crop Species Growing in Contaminated Soils. PLoS One 10:e0129936. https://doi.org/10.1371/journal.pone.0129936

Carter MR, Gregorich EG (2007) Soil Sampling and Methods of Analysis, Second Edition, 2nd Editio. CRC Press, Boca Raton, USA

Chang Q, Diao F, Wang Q, Pan L, Dang Z, Guo W (2018) Effects of arbuscular mycorrhizal symbiosis on growth, nutrient and metal uptake by maize seedlings (Zea mays L.) grown in soils spiked with Lanthanum and Cadmium. Environ Pollut 241:607-615. https://doi.org/10.1016/j.envpol.2018.06.003

Chen B, Nayuki K, Kuga Y, Zhang X, Wu S, Ohtomo R (2018) Uptake and intraradical immobilization of cadmium by arbuscular mycorrhizal fungi as revealed by a stable isotope tracer and synchrotron radiation $\mu \mathrm{x}$-ray fluorescence analysis. Microbes Environ 33:257-263. https://doi.org/10.1264/jsme2.ME18010

Chen BD, Liu Y, Shen H, Li XL, Christie P (2004) Uptake of cadmium from an experimentally contaminated calcareous soil by arbuscular mycorrhizal maize (Zea mays L.). Mycorrhiza 14:347-354. https://doi.org/10.1007/s00572-003-0281-2

Chen BD, Zhu YG, Duan J, Xiao XY, Smith SE (2007) Effects of the arbuscular mycorrhizal fungus Glomus mosseae on growth and metal uptake by four plant species in copper mine tailings. Environ Pollut 147:374-380. https://doi.org/10.1016/j.envpol.2006.04.027

Da Silva GA, Trufem SFB, Saggin Júnior OJ, Maia LC (2005) Arbuscular mycorrhizal fungi in a semiarid copper mining area in Brazil. Mycorrhiza 15:47-53. https://doi.org/10.1007/s00572-004-0293-6

Dupré de Boulois H, Joner EJ, Leyval C, Jakobsen I, Chen BD, Roos P, Thiry Y, Rufyikiri G, Delvaux B, Declerck S (2008) Role and influence of mycorrhizal fungi on radiocesium accumulation by plants. J Environ Radioact 99:785-800. https://doi.org/10.1016/j.jenvrad.2007.10.008

Dupré De Boulois H, Voets L, Delvaux B, Jakobsen I, Declerck S (2006) Transport of radiocaesium by arbuscular mycorrhizal fungi to Medicago truncatula under in vitro conditions. Environ Microbiol 8:1926-1934. https://doi.org/10.1111/j.1462-2920.2006.01070.x

Falandysz J, Sapkota A, Mędyk M, Feng X (2017) Rare earth elements in parasol mushroom Macrolepiota procera. Food Chem 221:24-28. https://doi.org/10.1016/j.foodchem.2016.10.047 
Grosjean N, Le Jean M, Berthelot C, Chalot M, Gross EM, Blaudez D (2019) Accumulation and fractionation of rare earth elements are conserved traits in the Phytolacca genus. Sci Rep 9:18458. https://doi.org/10.1038/s41598-019-54238-3

Guo W, Zhao R, Zhao W, Fu R, Guo J, Bi N, Zhang J (2013) Effects of arbuscular mycorrhizal fungi on maize (Zea mays L.) and sorghum (Sorghum bicolor L. Moench) grown in rare earth elements of mine tailings. Appl Soil Ecol 72:85-92. https://doi.org/10.1016/j.apsoil.2013.06.001

Han F, Shan X-Q, Zhang J, Xie Y-N, Pei Z-G, Zhang S-Z, Zhu Y-G, Wen B (2004) Organic acids promote the uptake of lanthanum by barley roots. New Phytol 165:481-492. https://doi.org/10.1111/j.14698137.2004.01256.x

Haselwandter K, Leyval C, Sanders FE (1994) Impact of arbuscular mycorrhizal fungi on plant uptake of heavy metals and radionuclides from soil. Impact Arbuscular Mycorrhizas Sustain Agric Nat Ecosyst 179-189. https://doi.org/10.1007/978-3-0348-8504-1_14

Hildebrandt U, Regvar M, Bothe H (2007) Arbuscular mycorrhiza and heavy metal tolerance. Phytochemistry 68:139-146. https://doi.org/10.1016/j.phytochem.2006.09.023

Hovsepyan A, Greipsson S (2004) Effect of Arbuscular Mycorrhizal Fungi on Phytoextraction by Corn ( Zea mays ) of Lead-Contaminated Soil. Int J Phytoremediation 6:305-321. https://doi.org/10.1080/16226510490888820

Hu R, Beguiristain T, De Junet A, Leyval C (2020) Bioavailability and transfer of elevated Sm concentration to alfalfa in spiked soils. Environ Sci Pollut Res xx:xxx-xxx. https://doi.org/10.1007/s11356-020-09223-z

Hu X, Ding Z, Chen Y, Wang X, Dai L (2002) Bioaccumulation of lanthanum and cerium and their effects on the growth of wheat (Triticum aestivum L.) seedlings. Chemosphere 48:621-629. https://doi.org/10.1016/S0045-6535(02)00109-1

Janoušková M, Pavlíková D, Macek T, Vosátka M (2005) Arbuscular mycorrhiza decreases cadmium phytoextraction by transgenic tobacco with inserted metallothionein. Plant Soil 272:29-40. https://doi.org/10.1007/s11104-004-3847-7

Jiang DG, Yang J, Zhang S, Yang DJ (2012) A survey of 16 rare earth elements in the major foods in China. Biomed Environ Sci 25:267-271. https://doi.org/10.3967/0895-3988.2012.03.003

Joner EJ, Briones R, Leyval C (2000) Metal-binding capacity of arbuscular mycorrhizal mycelium. Plant Soil 226:227-234. https://doi.org/10.1023/A:1026565701391

Joner EJ, Leyval C (1997) Uptake of 109Cd by roots and hyphae of a Glomus mosseae/Trifolium subterraneum mycorrhiza from soil amended with high and low concentrations of cadmium. New Phytol 135:353-360. https://doi.org/10.1046/j.1469-8137.1997.00633.x

Joner EJ, Leyval C (2001) Time-course of heavy metal uptake in maize and clover as affected by root density and different mycorrhizal inoculation regimes. Biol Fertil Soils 33:351-357. https://doi.org/10.1007/s003740000331

Joner EJ, Roos P, Jansa J, Frossard E, Leyval C, Jakobsen I (2004) No significant contribution of arbuscular mycorrhizal fungi to transfer of radiocesium from soil to plants. Appl Environ Microbiol 70:6512-6517. https://doi.org/10.1128/AEM.70.11.6512-6517.2004 
Kim RY, Yoon JK, Kim TS, Yang JE, Owens G, Kim KR (2015) Bioavailability of heavy metals in soils: definitions and practical implementation—a critical review. Environ Geochem Health 37:1041-1061. https://doi.org/10.1007/s10653-015-9695-y

Koske RE, Gemma JN (1989) A modified procedure for staining roots to detect VA mycorrhizas. Mycol Res 92:486-488. https://doi.org/10.1016/S0953-7562(89)80195-9

Lansman JB (1990) Blockade of current through single calcium channels by trivalent lanthanide cations. Effect of ionic radius on the rates of ion entry and exit. J Gen Physiol 95:679-696. https://doi.org/10.1085/jgp.95.4.679

Leyval C, Turnau K, Haselwandter K (1997) Effect of heavy metal pollution on mycorrhizal colonization and function: Physiological, ecological and applied aspects. Mycorrhiza 7:139-153. https://doi.org/10.1007/s005720050174

Li J, Hong M, Yin X, Liu J (2010) Effects of the accumulation of the rare earth elements on soil macrofauna community. J Rare Earths 28:957-964. https://doi.org/10.1016/S1002-0721(09)60233-7

Liang T, Li K, Wang L (2014) State of rare earth elements in different environmental components in mining areas of China. Environ Monit Assess 186:1499-1513. https://doi.org/10.1007/s10661-013-3469-8

MacMillan GA, Clayden MG, Chételat J, Richardson MC, Ponton DE, Perron T, Amyot M (2019) Environmental Drivers of Rare Earth Element Bioaccumulation in Freshwater Zooplankton. Environ Sci Technol 53:1650-1660. https://doi.org/10.1021/acs.est.8b05547

Massari S, Ruberti M (2013) Rare earth elements as critical raw materials: Focus on international markets and future strategies. Resour Policy 38:36-43. https://doi.org/10.1016/j.resourpol.2012.07.001

Merlos MA, Zitka O, Vojtech A, Azcón-Aguilar C, Ferrol N (2016) The arbuscular mycorrhizal fungus Rhizophagus irregularis differentially regulates the copper response of two maize cultivars differing in copper tolerance. Plant Sci 253:68-76. https://doi.org/10.1016/j.plantsci.2016.09.010

Pagano G (2016) Rare Earth Elements in Human and Environmental Health, 1st edn. Jenny Stanford, Singapore

Redon P-O, Béguiristain T, Leyval C (2008) Influence of Glomus intraradices on Cd partitioning in a pot experiment with Medicago truncatula in four contaminated soils. Soil Biol Biochem 40:2710-2712. https://doi.org/10.1016/j.soilbio.2008.07.018

Redon PO, Béguiristain T, Leyval C (2009) Differential effects of AM fungal isolates on Medicago truncatula growth and metal uptake in a multimetallic $(\mathrm{Cd}, \mathrm{Zn}, \mathrm{Pb})$ contaminated agricultural soil. Mycorrhiza 19:187-195. https://doi.org/10.1007/s00572-009-0230-9

Rivera-Becerril F (2002) Cadmium accumulation and buffering of cadmium-induced stress by arbuscular mycorrhiza in three Pisum sativum L. genotypes. J Exp Bot 53:1177-1185. https://doi.org/10.1093/jexbot/53.371.1177

Rivera-Becerril F, Van Tuinen D, Martin-Laurent F, Metwally A, Dietz KJ, Gianinazzi S, Gianinazzi-Pearson V (2005) Molecular changes in Pisum sativum L. roots during arbuscular mycorrhiza buffering of cadmium stress. Mycorrhiza 16:51-60. https://doi.org/10.1007/s00572-005-0016-7

Tonin C, Vandenkoornhuyse P, Joner EJ, Straczek J, Leyval C (2001) Assessment of arbuscular mycorrhizal fungi diversity in the rhizosphere of Viola calaminaria and effect of these fungi on heavy metal uptake by clover. Mycorrhiza 10:161-168. https://doi.org/10.1007/s005720000072 
Trouvelot A, Kough JL, Gianinazzi-Pearson V (1986) Mesure du taux de mycorhization VA d'un système radiculaire. Recherche de méthodes d'estimation ayant une signification fonctionnelle. Mycorrhizae Physiol Genet 217-221

Turnau K, Ryszka P, Gianinazzi-Pearson V, Van Tuinen D (2001) Identification of arbuscular mycorrhizal fungi in soils and roots of plants colonizing zinc wastes in southern Poland. Mycorrhiza 10:169-174. https://doi.org/10.1007/s005720000073

Vogel-Mikuš K, Drobne D, Regvar M (2005) Zn, Cd and Pb accumulation and arbuscular mycorrhizal colonisation of pennycress Thlaspi praecox Wulf. (Brassicaceae) from the vicinity of a lead mine and smelter in Slovenia. Environ Pollut 133:233-242. https://doi.org/10.1016/j.envpol.2004.06.021

Vogel-Mikuš K, Pongrac P, Kump P, Nečemer M, Regvar M (2006) Colonisation of a Zn, Cd and Pb hyperaccumulator Thlaspi praecox Wulfen with indigenous arbuscular mycorrhizal fungal mixture induces changes in heavy metal and nutrient uptake. Environ Pollut 139:362-371. https://doi.org/10.1016/j.envpol.2005.05.005

Wang L, Liang T (2014) Effects of exogenous rare earth elements on phosphorus adsorption and desorption in different types of soils. Chemosphere 103:148-155. https://doi.org/10.1016/j.chemosphere.2013.11.050

Weissenhorn I, Leyval C (1995) Root colonization of maize by a Cd-sensitive and a Cd-tolerant Glomus mosseae and cadmium uptake in sand culture. Plant Soil 175:233-238. https://doi.org/10.1007/BF00011359

Weissenhorn I, Leyval C, Belgy G, Berthelin J (1995) Arbuscular mycorrhizal contribution to heavy metal uptake by maize (Zea mays L.) in pot culture with contaminated soil. Mycorrhiza 5:245-251. https://doi.org/10.1007/s005720050068

Weissenhorn I, Leyval C, Berthelin J (1993) Cd-tolerant arbuscular mycorrhizal (AM) fungi from heavy-metal polluted soils. Plant Soil 157:247-256. https://doi.org/10.1007/BF00011053

Wu S, Zhang X, Sun Y, Wu Z, Li T, Hu Y, Lv J, Li G, Zhang Z, Zhang J, et al (2016) Chromium immobilization by extra- and intraradical fungal structures of arbuscular mycorrhizal symbioses. J Hazard Mater 316:34-42. https://doi.org/10.1016/j.jhazmat.2016.05.017

Yuan M, Guo M-N, Liu W-S, Liu C, van der Ent A, Morel JL, Huot H, Zhao W-Y, Wei X-G, Qiu R-L, et al (2017) The accumulation and fractionation of Rare Earth Elements in hydroponically grown Phytolacca americana L. Plant Soil 421:67-82. https://doi.org/10.1007/s11104-017-3426-3

Zhang DY, Shen XY, Ruan Q, Xu XL, Yang SP, Lu Y, Xu HY, Hao FL (2014) Effects of subchronic samarium exposure on the histopathological structure and apoptosis regulation in mouse testis. Environ Toxicol Pharmacol 37:505-512. https://doi.org/10.1016/j.etap.2014.01.007

Zhang HH, Tang M, Chen H, Zheng CL, Niu ZC (2010) Effect of inoculation with AM fungi on lead uptake, translocation and stress alleviation of Zea mays L. seedlings planting in soil with increasing lead concentrations. Eur J Soil Biol 46:306-311. https://doi.org/10.1016/j.ejsobi.2010.05.006 
Table 1 Physico-chemical characteristics of the soil used in the experiment

\begin{tabular}{|c|c|c|}
\hline Soil parameter & Value & Methods \\
\hline $\mathrm{pH}$ & 6.68 & ISO 10390 \\
\hline sand: silt: clay (\%) & $167: 513: 320$ & NF X 31-107 \\
\hline Organic carbon $\left(\mathrm{g} \cdot \mathrm{kg}^{-1}\right)$ & 15.8 & ISO 14235 \\
\hline Total nitrogen $\left(\mathrm{g} \cdot \mathrm{kg}^{-1}\right)$ & 1.65 & ISO 14235 \\
\hline Organic matter $\left(\mathrm{g} \cdot \mathrm{kg}^{-1}\right)$ & 27.4 & $\overline{\text { ISO } 14235}$ \\
\hline $\mathrm{C} / \mathrm{N}$ & 9.6 & ISO 14235 \\
\hline Olsen P $\left(\mathrm{mg} \cdot \mathrm{kg}^{-1}\right)$ & 91 & $\overline{\text { ISO } 11263}$ \\
\hline $\mathrm{Ca}\left(\mathrm{cmol}+\cdot \mathrm{kg}^{-1}\right)$ & 13.1 & $\overline{\text { ISO } 23470}$ \\
\hline $\mathrm{Mg}\left(\mathrm{cmol}+\cdot \mathrm{kg}^{-1}\right)$ & 1.79 & $\overline{\text { ISO23470 }}$ \\
\hline $\mathrm{Na}\left(\mathrm{cmol}+\cdot \mathrm{kg}^{-} 1\right)$ & 0.11 & ISO23470 \\
\hline $\mathrm{K}\left(\mathrm{cmol}+\cdot \mathrm{kg}^{-} 1\right)$ & 1.14 & $\overline{\text { ISO23470 }}$ \\
\hline $\mathrm{Fe}\left(\mathrm{cmol}^{+} \cdot \mathrm{kg}^{-} 1\right)$ & 0.01 & $\overline{\text { ISO23470 }}$ \\
\hline $\mathrm{Mn}\left(\mathrm{cmol}+\cdot \mathrm{kg}^{-} 1\right)$ & 0.3 & $\overline{\text { ISO23470 }}$ \\
\hline $\mathrm{Al}\left(\mathrm{cmol}+\cdot \mathrm{kg}^{-1} 1\right)$ & 0.050 & ISO 23470 \\
\hline
\end{tabular}

Table 2 Mycorrhizal colonization of roots in the two experiments (Trouvelot et al.1986). Means followed by the same letter do not differ significantly using using one-way ANOVA on arcsine transformed data $(\mathrm{p}<0.05)$. M: Funneliformis mosseae inoculated alfalfa plants, NM: non inoculated alfalfa plant

\begin{tabular}{|c|c|c|c|c|c|}
\hline & treatment & $\begin{array}{c}\text { Mycorrhizal frequency } \\
\text { (F\%, \% of colonized } \\
\text { roots) } \\
\end{array}$ & $\begin{array}{l}\text { Mycorrhizal intensity } \\
\text { (M\%, \% of root length } \\
\text { colonized) }\end{array}$ & $\begin{array}{c}\text { Arbuscule } \\
\text { frequency } \\
(\mathbf{a} \%) \\
\end{array}$ & $\begin{array}{c}\text { Arbuscule } \\
\text { intensity } \\
(\mathrm{A} \%) \\
\end{array}$ \\
\hline \multirow{6}{*}{ Pot experiment } & $0 \mathrm{M}$ & $42.5 \pm 29.7 \mathrm{a}$ & $16.1 \pm 10.2 \mathrm{ab}$ & $10.1 \pm 7.1 \mathrm{a}$ & $2.1 \pm 1.8 \mathrm{a}$ \\
\hline & $0 \mathrm{NM}$ & 0 & 0 & 0 & 0 \\
\hline & $100 \mathrm{M}$ & $60.0 \pm 20.0 \mathrm{a}$ & $30.4 \pm 10.9 \mathrm{a}$ & $28.7 \pm 13.2 \mathrm{~b}$ & $8.0 \pm 2.9 \mathrm{~b}$ \\
\hline & $100 \mathrm{NM}$ & 0 & 0 & 0 & 0 \\
\hline & $200 \mathrm{M}$ & $15.0 \pm 16.9 \mathrm{a}$ & $5.7 \pm 7.0 \mathrm{~b}$ & $2.4 \pm 3.2 \mathrm{a}$ & $0.1 \pm 0.2 \mathrm{a}$ \\
\hline & $200 \mathrm{NM}$ & 0 & 0 & 0 & 0 \\
\hline \multirow{4}{*}{$\begin{array}{c}\text { Compartment } \\
\text { device experiment }\end{array}$} & $37-\mathrm{M}$ & $28.9 \pm 8.4 \mathrm{a}$ & $17.3 \pm 2.7 \mathrm{a}$ & $32.7 \pm 14.8 \mathrm{a}$ & $5.4 \pm 1.9 \mathrm{a}$ \\
\hline & 37-NM & 0 & 0 & 0 & 0 \\
\hline & Air-M & $25.6 \pm 3.8 \mathrm{a}$ & $16.4 \pm 5.4 \mathrm{a}$ & $22.8 \pm 16.1 \mathrm{a}$ & $3.7 \pm 2.4 \mathrm{a}$ \\
\hline & Air-NM & 0 & 0 & 0 & 0 \\
\hline
\end{tabular}


a)

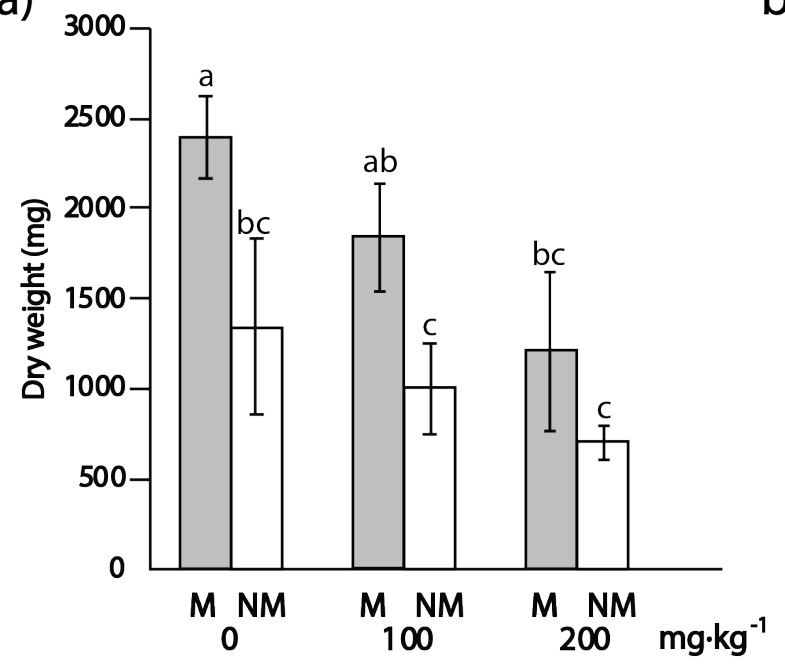

b)

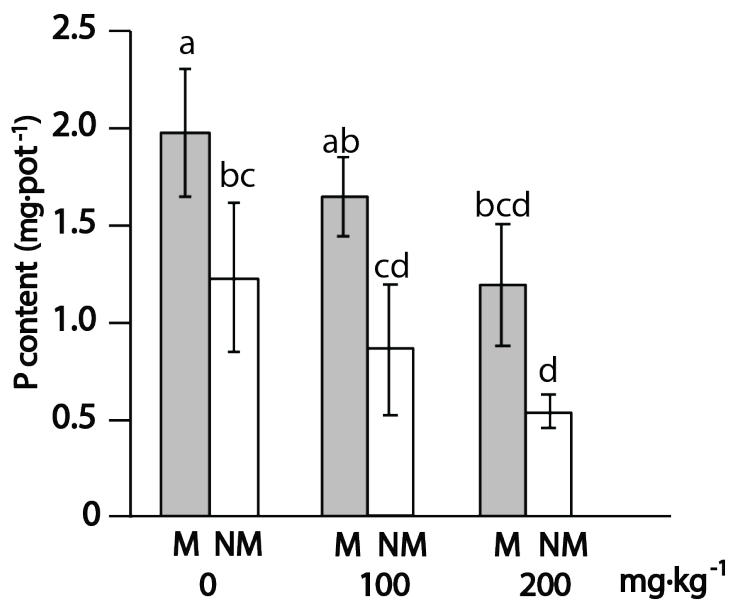

Fig. 1 a) Alfalfa shoot dry weight (total per pot) and b) $\mathrm{P}$ content of alfalfa shoots as a function of spiked Sm concentration $\left(0,100\right.$ and $\left.200 \mathrm{mg} \mathrm{kg}^{-1}\right)$ and with $(\mathrm{M})$ and without (NM) arbuscular mycorrhizal inoculation in pot experiment. Means followed by the same letter do not differ significantly using two-way ANOVA and Tukey (HSD) post-hoc test $(P<0.05)$

a)

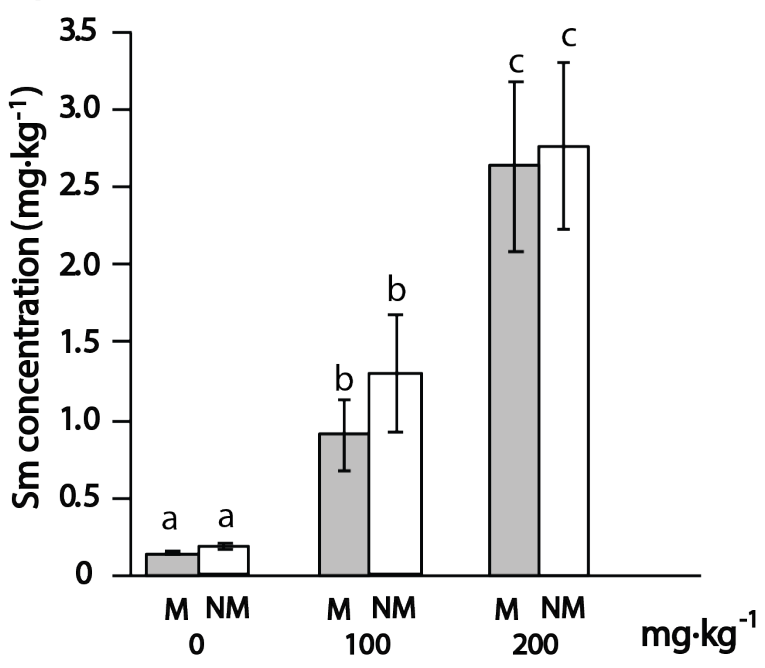

b)

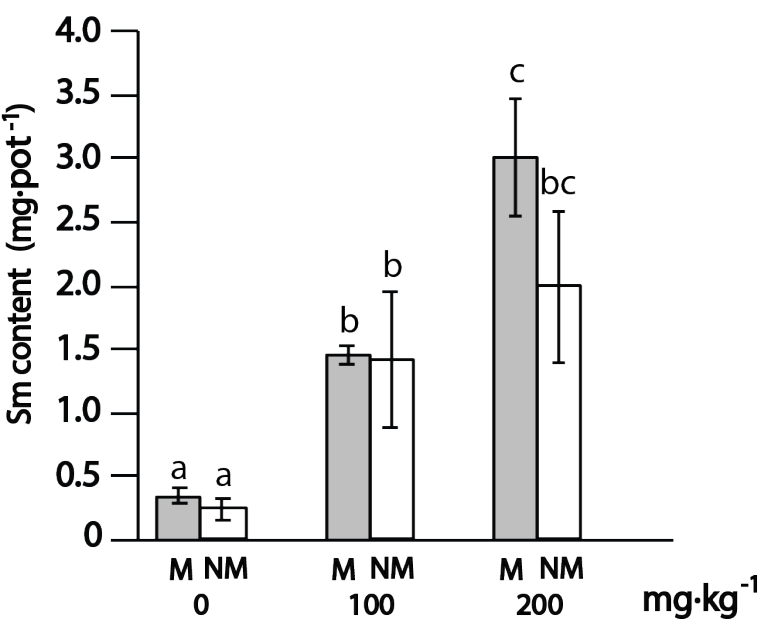

Fig. $2 \mathrm{Sm}$ a) concentration and b) content of alfalfa shoots as a function of Sm spiked concentration $(0,100$ and $200 \mathrm{mg} \mathrm{kg}^{-1}$ ) with (M) and without (NM) arbuscular mycorrhizal inoculation in pot experiment. Means followed by the same letter do not differ significantly using two-way ANOVA on rank-transformed data and Tukey (HSD) post-hoc test $(P<0.05)$ 
a)

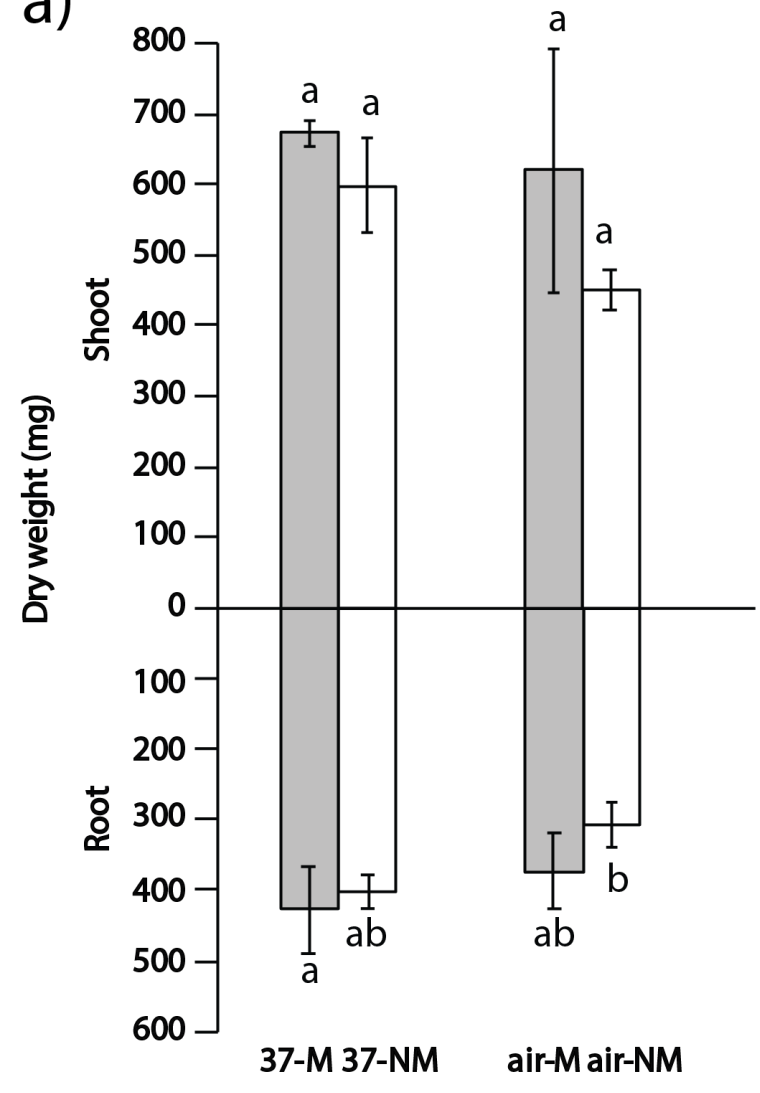

b)

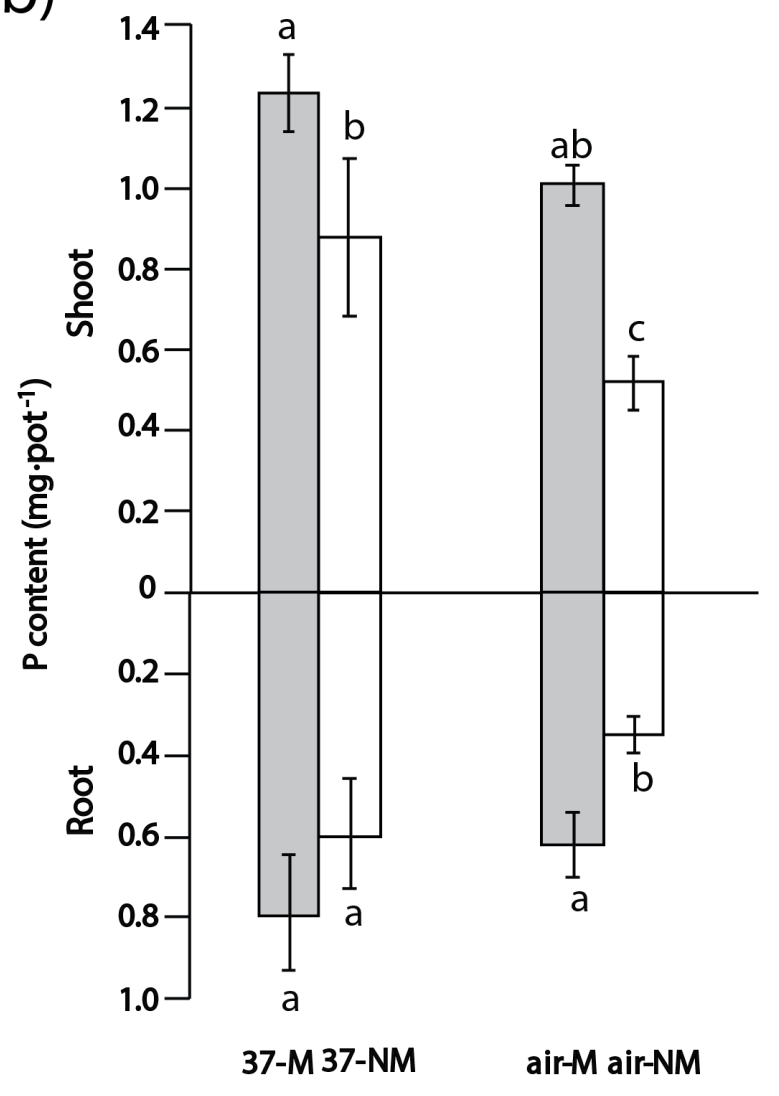

Fig. 3 a) Alfalfa shoot dry weight (total per pot) and b) $P$ content of alfalfa shoots in compartment devices with $37 \mu \mathrm{m}$ (37) or 37-1000-37 $\mu \mathrm{m}$ (air) mesh with (M) and without (NM) arbuscular mycorrhizal inoculation. Means followed by the same letter do not differ significantly using two-way ANOVA and Tukey (HSD) post-hoc tests $(P<0.05)$ 

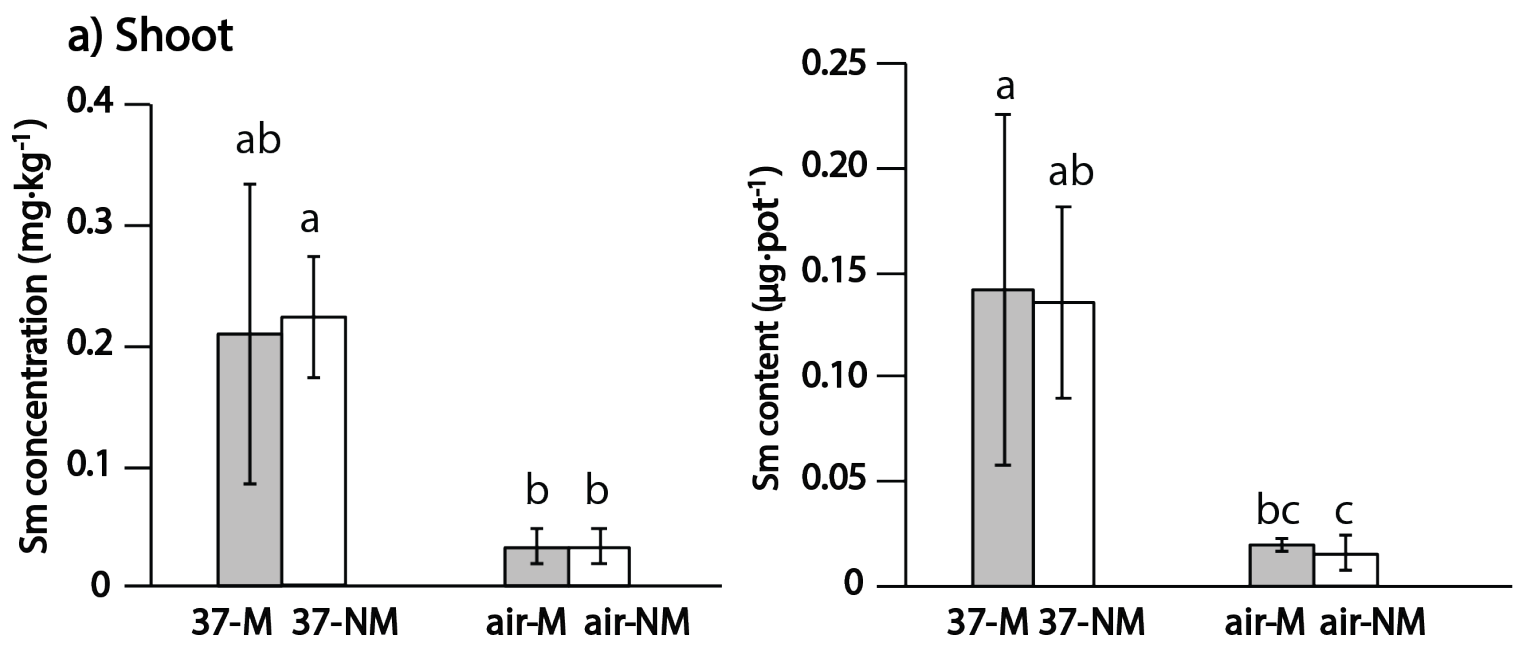

\section{b) Root}
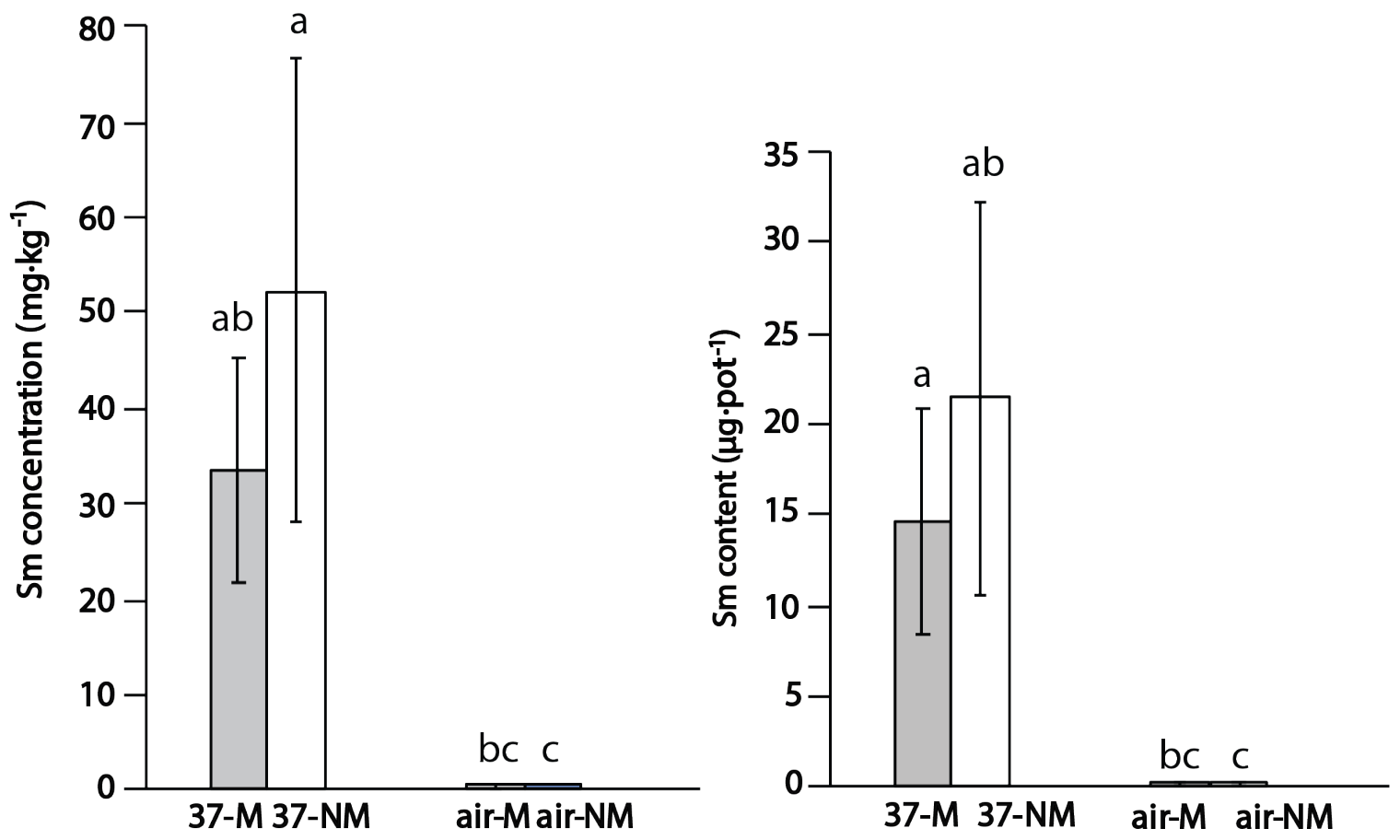

Fig. $4 \mathrm{Sm}$ concentration and content of alfalfa a) shoots and b) roots in compartment devices with $37 \mu \mathrm{m}(37)$ or 37-1000-37 $\mu \mathrm{m}$ (air) mesh with (M) and without (NM) arbuscular mycorrhizal inoculation. Rank transformed data were used for shoot Sm content, root Sm concentration and root Sm content. Means followed by the same letter do not differ significantly using two-way ANOVA and Tukey (HSD) post-hoc test $(P<0.05)$ 


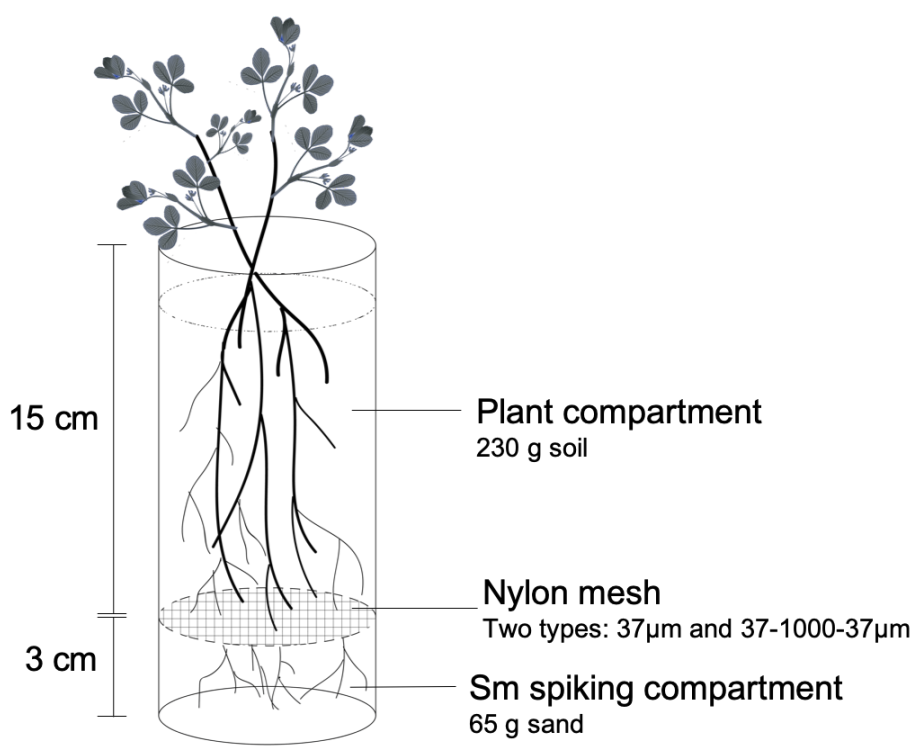

Supplementary Fig. 1 Compartmented pots used in the second experiment 
a) $P$

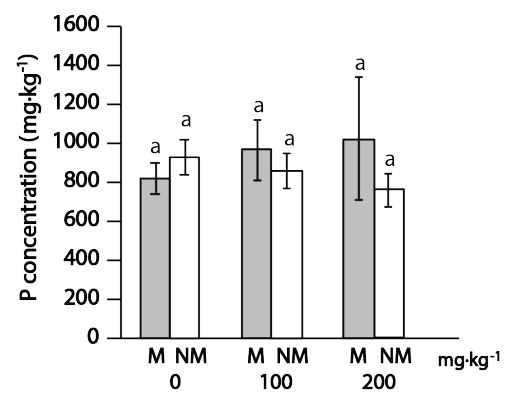

b) $\mathrm{Na}$
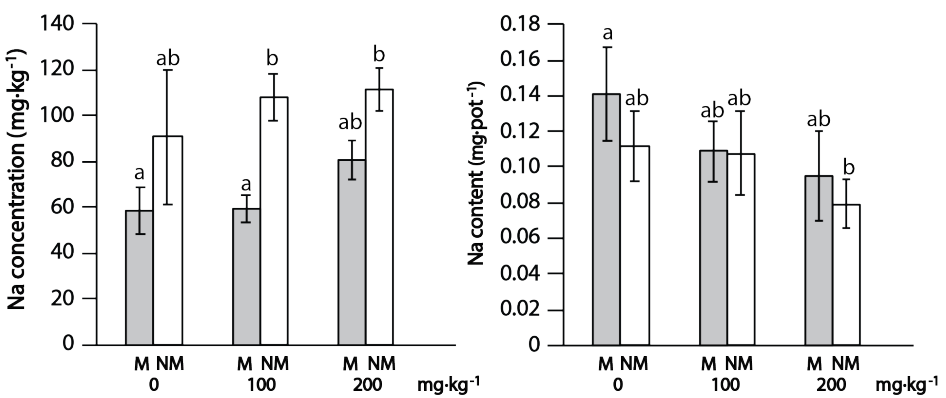

c) $\mathrm{Mg}$
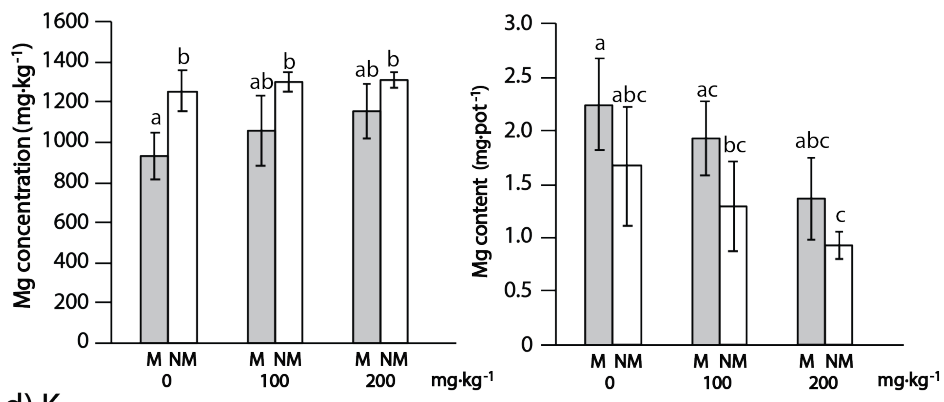

d) $\mathrm{K}$
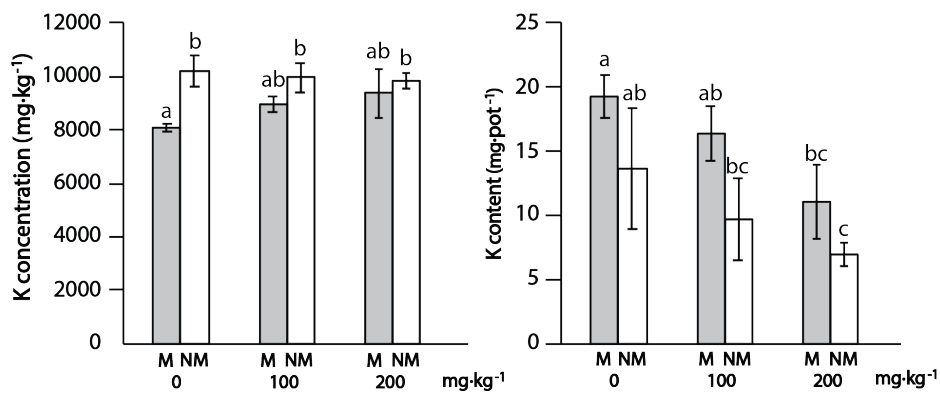

e) $\mathrm{Ca}$
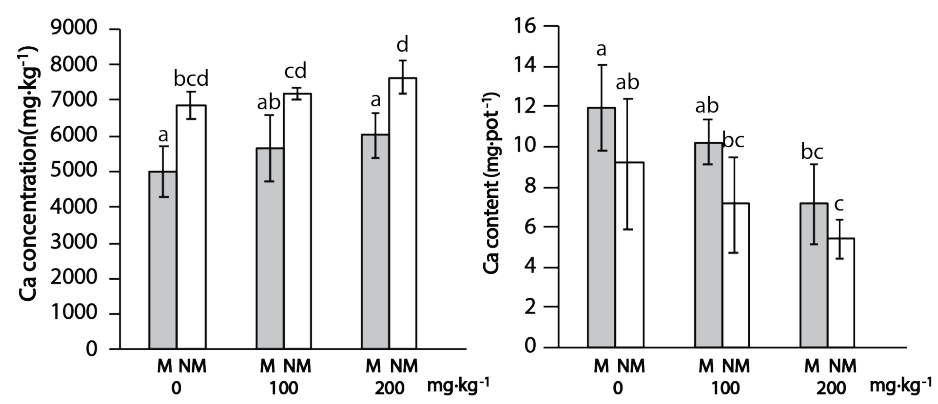

Supplementary Fig. 2 Concentrations of a) P b) Na c) Mg d) K e) Ca and content of b) $\mathrm{Na}$ c) Mg d) K e) Ca of alfalfa shoots as a function of Sm spiked concentration $\left(0,100\right.$ and $\left.200 \mathrm{mg} \mathrm{kg}^{-1}\right)$ with (M) and without (NM) arbuscular mycorrhizal inoculation in pot experiment. Means followed by the same letter do not differ 
significantly_using two-way ANOVA and Tukey (HSD) post-hoc tests $(P<0.05)$. Rank transformed data were used for $\mathrm{K}, \mathrm{Mg}$ and $\mathrm{P}$ concentrations.

a)

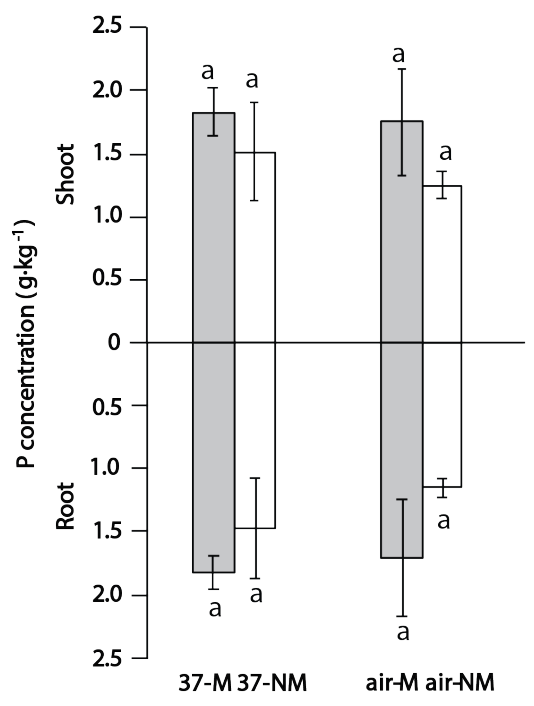

b)

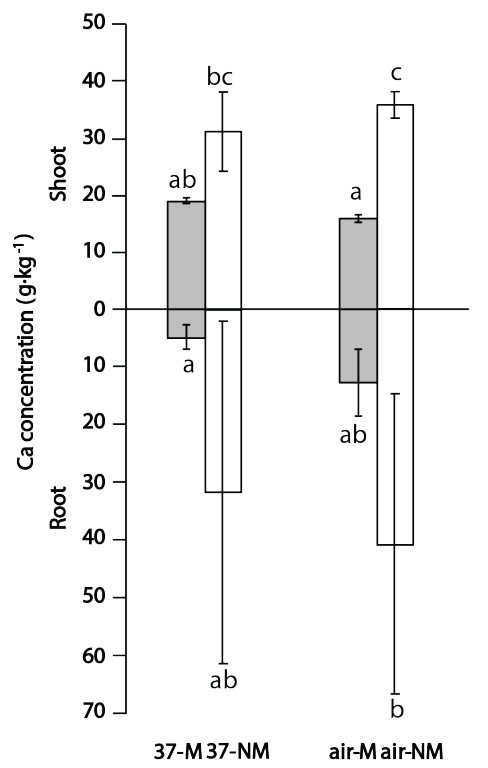

c)

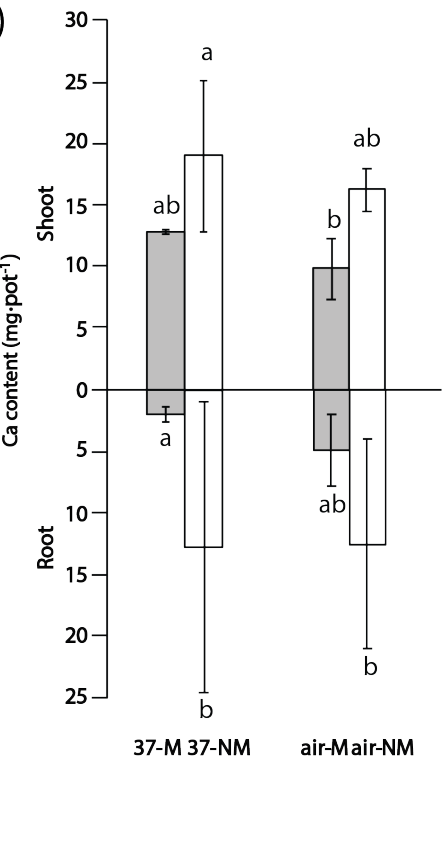

Supplementary Fig. 3 a) $\mathrm{P}$ concentration b) Ca concentration and c) Ca content of alfalfa shoots and roots in compartmented pots with $37 \mu \mathrm{m}$ (37) or 37-1000-37 $\mu \mathrm{m}$ (air) mesh with (M) and without (NM) arbuscular mycorrhizal inoculation. Means followed by the same letter do not differ significantly using two-way ANOVA and Tukey (HSD) post-hoc tests $(P<0.05)$. Rank transformed data were used for shoot Ca concentration, root $\mathrm{Ca}$ concentration and root $\mathrm{Ca}$ content. 